\title{
CONTRIBUTION TO THE MOSQUITO FAUNA (DIPTERA, CULICIDAE) OF LIKA, CENTRAL CROATIA, WITH SPECIAL REFERENCE TO INVASIVE SPECIES
}

\author{
Nataša Bušić, Matej Modrušan, Helena Vilc \& Enrih Merdić ${ }^{*}$ \\ Josip Juraj Strossmayer University of Osijek, Department of biology, Cara Hadrijana 8/A, \\ 31000 Osijek, Croatia
}

Bušić, N., Modrušan, M., Vilc, H. \& Merdić, E.: Contribution to the mosquito fauna (Diptera, Culicidae) of Lika, central Croatia, with special reference to invasive species. Nat. Croat., Vol. 30, No. 1, 231-242, Zagreb, 2021.

This study of mosquitoes in Lika, geographically, geologically and climatically a very specific region, was conducted to gain insight into the composition and relative abundance of the mosquito fauna, as well as to check for the possible presence of invasive species. Sampling took place from July to September 2020. Mosquito larvae were captured from medium and small breeding sites using a 25 $\mathrm{cm}$ diameter net and a plastic dipper. Adult specimens were sampled in both urban and rural areas using $\mathrm{CO}_{2}$ baited CDC traps, $\mathrm{CO}_{2}$ baited BG Sentinel traps with BG Lure and human landing catch. The study was conducted at 69 sites. We collected 5,126 specimens (100 adults and 5,026 larvae) and demonstrated the presence of 16 mosquito species. CDC traps were almost five times more effective (quantity and quality) than BG Sentinel traps. The most common mosquito taxa caught in Lika were Culex pipiens complex (78.36\% of all larvae) and Ae. geniculatus (30.26\% of all adults). Both invasive mosquito species present in Croatia, Aedes albopictus and Ae. japonicus, were recorded, with Ae. albopictus being detected in Lika for the first time. Aedes japonicus was widespread, recorded in 23 localities. According to molecular analysis, only An. maculipennis s.s. was confirmed in the An. maculipennis complex. Within the $C x$. pipiens complex, both $C x$. pipiens biotypes, pipiens and molestus were confirmed together with one single hybrid specimen. Analysis of mosquito occurrence with regard to altitude shows that most samples and species were collected between 601 and $700 \mathrm{~m}$ a.s.l., although the Shannon evenness index and Hill's index show the highest value in the range of 901 to $1140 \mathrm{~m}$ a.s.l. In this systematic study on the mosquito fauna in Lika, a significant species diversity, including invasive species, was found.

Key words: mosquitoes, fauna, invasive species, altitude dispersal, Lika

Bušić, N., Modrušan, M., Vilc, H. \& Merdić, E.: Prilog poznavanju komaraca (Diptera, Culicidae) Like, središnja Hrvatska, s posebnim osvrtom na prisutnost invazivnih vrsta. Nat. Croat., Vol. 30, No. 1, 231-242, Zagreb, 2021.

Istraživanje komaraca u Lici, geografski, geološki i klimatski vrlo specifičnoj regiji, provedeno je kako bi se stekao uvid u faunu i brojnost komaraca, kao i da bi se utvrdila moguća prisutnost invazivnih vrsta. Uzorkovanje se odvijalo od srpnja do rujna 2020. godine. Ličinke komaraca uzorkovane su u srednjim i malim leglima mrežicom promjera $25 \mathrm{~cm}$ i plastičnim posudicama. Uzorkovanje odraslih komaraca u urbanim i ruralnim područjima obavljeno je koristeći CDC klopke uz suhi led kao atraktant, BG Sentinel klopke uz BG Lure i suhi led kao atraktant i metodom čovjek-aspirator. Istraživanje je provedeno na 69 postaja. Uzorkovano je 5126 jedinki (100 odraslih i 5026 ličinki) i utvrđena prisutnost 16 vrsta komaraca. CDC klopke bile su gotovo pet puta kvantitativno učinkovitije od BG Sentinel klopki. Najrasprostranjenija i najbrojnija vrsta komaraca uzorkovana u Lici bila

* corresponding author: enrih@biologija.unios.hr 
je Culex pipiens kompleks (78,36\% svih ličinki) i Ae. geniculatus (30,26\% svih odraslih). Zabilježene su obje invazivne vrste komaraca prisutne u Hrvatskoj, Aedes albopictus i Ae. japonicus, s tim da je Ae. albopictus prvi put zabilježen u Lici. Ae. japonicus je široko rasprostranjen, zabilježen na 23 postaje. Prema molekularnoj analizi, unutar kompleksa An. maculipennis potvrđena je prisutnost samo An. maculipennis s. s. Unutar kompleksa $C x$. pipiens, potvrđena su oba biotipa, $C x$. pipiens pipiens i $C x$. pipiens molestus te jedna hibridna jedinka. Analiza pojave komaraca s obzirom na nadmorsku visinu pokazuje da je većina uzoraka i vrsta prikupljena na nadmorskoj visini od 601 do $700 \mathrm{~m}$, iako Shannonov indeks ravnomjernosti i Hillov indeks pokazuju najveću vrijednost na nadmorskoj visini 901 do $1140 \mathrm{~m}$. Ovim sustavnim istraživanjem faune komaraca u Lici utvrđena je značajna raznolikost vrsta, uključujući i invazivne vrste.

Ključne riječi: komarci, fauna, invazivne vrste, rasprostranjenost na nadmorskim visinama, Lika

\section{INTRODUCTION}

Lika is a geographical region in southwestern Croatia. It forms a plateau between Velebit Mountain to the west and south, Lička Plješivica Mountain to the east and Kapela Mountain to the northwest. The northern border is rather vague because the Ogulin-Plašćanska valley forms a transitional area between Lika and Gorski Kotar. Lika is specific for its karst relief, formed of permeable rocks mainly composed of limestone and dolomite. The climate is continental to mountainous, resultant upon Velebit being a barrier.

Because of the permeable substrate (karstic), water does not stay on the surface for long, and there are no significant stagnant water bodies. Nevertheless, due to the high amount of precipitation, there are many potential habitats for the aquatic development of mosquitoes, since water may accumulate in plenty of man-made constructions and containers such as canals, pools, rainwater barrels, buckets, machinery, tyres, etc.

Information on the geographical distribution of mosquitoes is very important for mosquito control and the management of mosquito-borne diseases (GIMNIG et al., 2005; Palaniyand, 2014). The abundance of mosquitoes depends primarily on biotic factors, but abiotic factors related to climate and landscape also play a significant role (HonghOH et al., 2012). To better understand all changes occurring globally, data on the occurrence of mosquito species are needed, especially of invasive species. Although mosquitoes are vectors of pathogens of various diseases, not a single case of vector-borne disease has recently been reported from the Lika area. This could be a reason why this area has not been of particular interest to researchers.

Mosquitoes are well studied in many areas of Croatia (Merdić et al., 2020a). So far, 52 mosquito species have been recorded in Croatia (Merdić et al., 2020b), two of which are the invasive species Aedes albopictus and Aedes japonicus. Since their first detection (KLOBUČAR et al., 2006, 2014), these two species have spread to most parts of Croatia (CAPAK et al., 2017; Janssen et al., 2020). Due to the small population and relatively low numbers, the mosquitoes of Lika have been discussed in only a few papers (Adamović \& Paulus, 1985.; Vignjević, 2014.; Merdić et al., 2018; Janssen et al., 2020; Bušić et al., 2021), in which 11 species were recorded.

Accurate identification of mosquitoes is critical to establish effective mosquito control programmes and strategies. Identification is commonly based on morphological determination of females and fourth-stage larvae, but this is not possible if parts of the mosquito needed for determination are damaged or missing (HEBERT et al., 2003). Moreover, mosquitoes very often occur as complexes of species, the members of 
which are difficult to distinguish morphologically, or the differences required for determination are limited to a certain sex or life stage of a particular species (Khrabrova et al., 2013). Therefore, morphological determination must often be supplemented by molecular determination.

Despite the low health-related impact of mosquitoes in Lika and the relatively low abundance, mosquito research in this area may be interesting from the point of view of biodiversity in a karst area and the spread of invasive species.

\section{STUDY AREA}

According to the climate classification of Koppen, the area of Lika belongs to the climate class "Cfsbx" (C - temperate rainy climate, fs - no dry periods and the highest monthly precipitation in the cold part of the year, $b$ - the warmest months of the year have an average temperature of less than $22^{\circ} \mathrm{C}, \mathrm{x}-$ two maxima in the annual course of precipitation in autumn and winter/spring), while the mountain peaks (above $1200 \mathrm{~m}$ a.s.1.) belong to the class "Dfsbx" (D - snow-forest climate). Due to the strong orographic indentation of the Lika area, mean annual air temperatures range from $5^{\circ} \mathrm{C}$ to $9^{\circ} \mathrm{C}$ (in winter (January) from $-4^{\circ} \mathrm{C}$ to $0^{\circ} \mathrm{C}$ and in summer (July) from $15^{\circ} \mathrm{C}$ to $20^{\circ} \mathrm{C}$ ). In terms of the annual pattern of monthly precipitation, the Lika region belongs to the maritime type. The average precipitation ranges from 1200 to 1800 $\mathrm{mm}$, with more precipitation in the cold part of the year. The maximum occurs in November and the minimum in July. A snow cover of at least $30 \mathrm{~cm}$ remains on the ground on the Lika plateau for 18 days in January.

\section{MATERIAL AND METHODS}

The sampling took place from July to September 2020 in the Lika region. In Fig. 1, all sites covered by this survey are presented according to sampling method: CDC traps (ten sites), BG-Sentinel traps (five sites), larval sampling (53 sites) and human landing catch (one site). All sampled sites were georeferenced using the mobile application GPS Essentials. Altitude of sampling sites ranged from 413 to $1139 \mathrm{~m}$.

\section{Mosquito collection}

During this study, both larval and adult mosquitoes were collected. Larvae were sampled from medium-sized breeding sites $\left(1-100 \mathrm{~m}^{2}\right)$ with a $25 \mathrm{~cm}$ diameter net and from smaller water bodies $\left(\leq 1 \mathrm{~m}^{2}\right)$, such as used car tyres, barrels, buckets, vases, cans, tubs, and tree holes with plastic dippers. Adult specimens were caught in both urban and forested areas using a variety of methods: CDC traps baited with $\mathrm{CO}_{2}$, BG-Sentinel traps (BGS) baited with $\mathrm{CO}_{2}$ and BG Lure, and human landing catch. CDC and BGS traps were operated three times during the season (Tab. 1). Traps were set at dusk, collected in the morning and run for approximately 12 hours. The areas where the CDC traps were set were carefully selected for microclimatic conditions suitable for mosquitoes, such as shaded places with vegetation. BGS traps were set attyre repair shops. Human landing catch was performed only once at dusk during the high activity period of mosquitoes. The sampling methods are described in detail in MERdić et al. (2020a). 


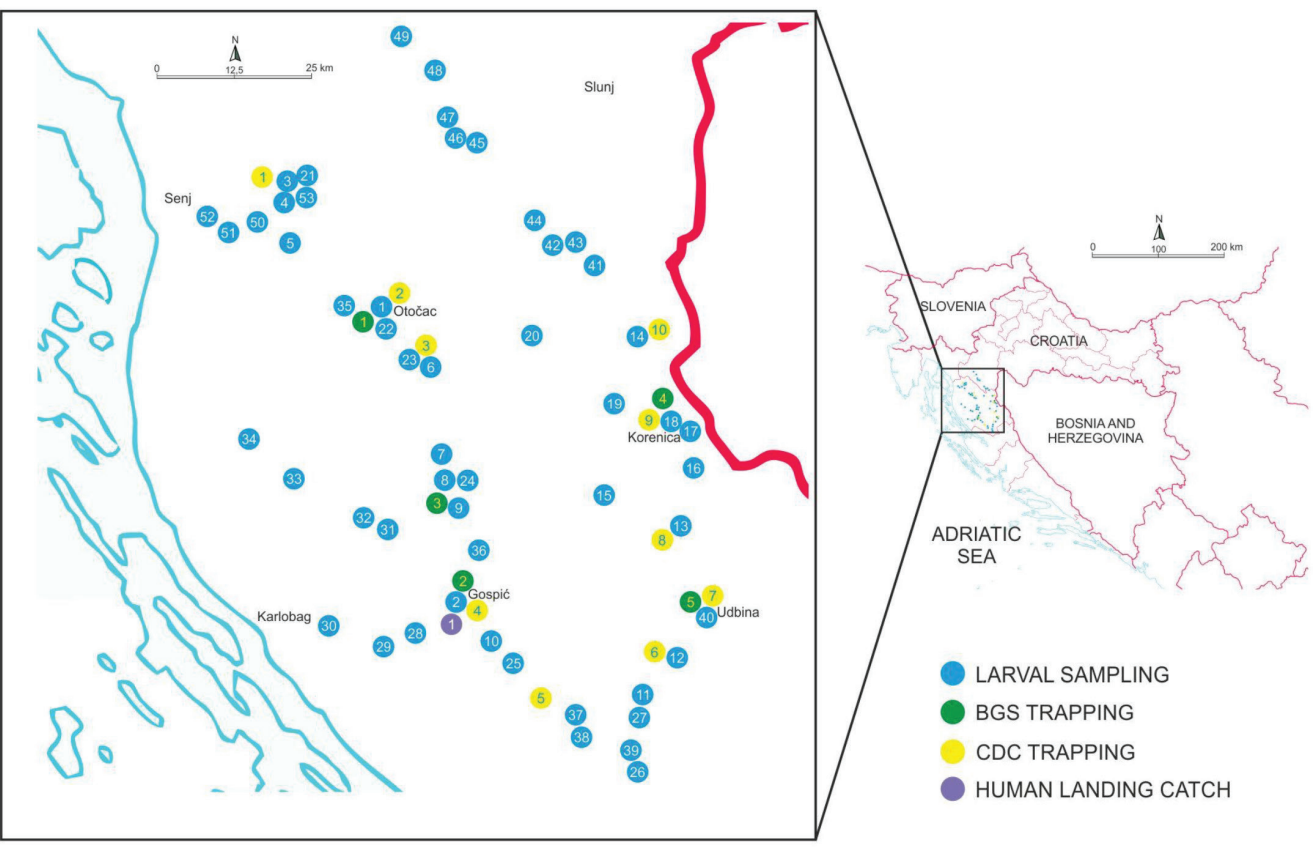

Fig. 1. Mosquito sampling sites in Lika

Legend: Larval sampling: 1. Otočac, 2. Gospić, 3. Brinje, 4. Brinje 2, 5 jezero Gušić, 6 Ličko Lešće, 7. Ličko Lešće, 8. Kvarte, 9. Perušić, 10. Bilaj, 11. Gornja ploča, 12. Kurjak, 13. Pećane, 14. Jezerce, 15. Bunić, 16. Bijelo Polje, 17. Korenica, 18. Korenica, 19. Humoljac, 20. Donji Babin Potok, 21. Brinje, 22. Otočac, 23. Ličko Lešće, 24. Kvarte, 25. Lički Ribnik, 26. Sveti Rok, 27. Lovinac, 28. Trnovačko Novoselo, 29. Brušane, 30. Baške Oštarije, 31. Vranovine, 32. Aleksinica, 33. Pazariški Bakovac, 34. Sj. Velebit, 35. Otočac, 36. Lički Osik, 37. Papuča, 38. Raduč, 39. Sv Rok (ili Jurjevićí), 40. Udbina, 41. Poljanak, 42. Kuselj, 43. Kuselj, 44. Saborsko, 45. Lapat, 46. Lapat, 47. Plaški, 48. Vojnovac, 49. Josipdol, 50. Žuta Lokva, 51. Melnice, 52. Vratnik, 53. Brinje BG Sentinel trapping: 1. Otočac, 2. Perušić, 3. Gospić, 4. Udbina, 5. Korenica

CDC trapping: 1. Brinje, 2. Otočac 3. Ličko Lešće, 4. Gospić, 5. Medak, 6. Kurjak, 7. Udbina 8. Pećane, 9. Korenica, 10. Jezerce

Human landing catch: 1. Gospić

All sampled adult mosquitoes were killed by freezing at temperatures below $0{ }^{\circ} \mathrm{C}$ or with cigarette smoke and mounted on entomological pins. The sampled larvae were preserved in $96 \%$ alcohol for molecular analysis.

\section{Mosquito identification}

All mosquitoes were morphologically identified according to Gutshevich et al. (1974) and Becker et al. (2010). Cryptic species within the Anopheles maculipennis complex were identified using molecular methods based on polymerase chain reaction of ribosomal DNA according to Di LuCA et al. (2014). Following SMith \& Fonseca (2004) and BAHnK \& FonseCA (2006), the Culex pipiens complex was analysed for occurrence of $C x$. torrentium and the pipiens/molestus biotypes of $C x$. pipiens s.s. Three specimens of that complex were taken from each locality for molecular analysis, if there was more than one. All mounted mosquitoes are kept in the entomological collection of the Department of Biology, Josip Juraj Strossmayer University in Osijek. 
Tab. 1. Total number of individuals collected per locality by different methods during three samplings

\begin{tabular}{|l|c|c|c|l|}
\hline \multicolumn{1}{|c|}{ date } & 8-10 July & 22-25 July & 2-5 Sept. & \\
\hline \multicolumn{1}{|c|}{ locality } & \multicolumn{2}{c|}{ number of individuals } \\
\hline Brinje & 0 & 0 & 1 & CDC trap \\
\hline Otočac & 1 & 2 & 0 & CDC trap \\
\hline Ličko Lešće & 0 & 4 & 1 & CDC trap \\
\hline Medak & 8 & 0 & 2 & CDC trap \\
\hline Gospić & 1 & 19 & 6 & CDC trap \\
\hline Pećane & 1 & 2 & 0 & CDC trap \\
\hline Korenica & 1 & 2 & 0 & CDC trap \\
\hline Jezerce & 1 & 8 & 11 & CDC trap \\
\hline Kurjak & 0 & 0 & 1 & CDC trap \\
\hline Udbina & 2 & 0 & 2 & CDC trap \\
\hline Gospić & - & - & 9 & HLC** \\
\hline Otočac & 1 & 0 & 4 & BGS trap \\
\hline Gospi*́ & 0 & 0 & 0 & BGS trap \\
\hline Perušić & 4 & 1 & 5 & BGS trap \\
\hline Korenica & 0 & 0 & 0 & BGS trap \\
\hline Udbina & 0 & 0 & BGS trap \\
\hline
\end{tabular}

*CDC - CDC trap baited with $\mathrm{CO}_{2}$

**BGS - BG-Sentinel trap baited with $\mathrm{CO}_{2}$ and BG lure

***HLC - Human lending catch

\section{Statistical analysis}

The analysis was performed using ComEcoPaC (version 1, DrozD, 2010). Species diversity was analysed using the Shannon evenness index (E) and Hill's index (N2). The Shannon evenness index $\left(\mathrm{E}=\mathrm{H}^{\prime}\right.$ / $\left.\mathrm{Hmax}\right)$ takes values between 0 and 1 , where a value closer to ' 0 ' represents lower evenness (the dominance of one species) and a value closer to ' 1 ' represents full evenness (an even abundance of species). The value of $t$ Hill's index (inverse Simpson index) starts with 1 as the lowest possible value. The higher the value of this index, the greater the diversity. To compare the similarity of the samples, Jaccard's similarity index (Ja) was used.

\section{RESULTS}

The total number of mosquitoes sampled in the study was 5,126. One hundred of these were caught as adults, using CDC traps (76 specimens), BGS traps (15 specimens) and human landing catch (9 specimens). All other individuals were collected from different water bodies at the larval stage. A total of 16 species within 5 genera were recorded (Culex - 4 species; Aedes -6 species; Anopheles - 3 species; Culiseta - 2 species; Coquillettidia - 1 species). The collected taxa are: $C x$. pipiens s.s. (biotype pipiens and biotype molestus), Cx. torrentium, Cx. hortensis, Cx. territans, Ae. japonicus, Ae. albopictus, Ae. vexans, Ae. geniculatus, Ae. sticticus, Ae. cantans, An. maculipennis s.s., An. claviger, An. plumbeus, Cs. annulata, Cs. longiareolata and Cq. richiardii. 
In all three CDC trap samplings, the number of mosquitoes ranged from 0 to 19 per site. The highest number of mosquitoes was caught in July. Two localities stand out for the large number of mosquitoes: Gospić with 26 and Jezerce with 20 mosquitoes. At other localities, significantly fewer or no mosquitoes were caught (Tab. 1). Eudominant species were Ae. geniculatus (30.26\%), collected at localities 4, 5, 7 and 10 (below, localities are marked with numbers according to the map in Fig. 1) and Ae. sticticus $(27.63 \%)$, caught at localities $2,3,4,5$ and 8 . The dominant species were Ae. vexans $(14.47 \%)$, sampled at localities $2,3,4,6$ and 10 and An. plumbeus $(10.52 \%)$, sampled at localities 4 and 10 . Other species accounted for $17.10 \%$ of the mosquitoes collected. Among them, members of the $C x$. pipiens complex were sampled at localities 1, 7 and 9, members of the An. maculipennis complex at localities 3, 5 and 8, two individuals of Cs. longiareolata at locality 9 and one individual of $C q$. richiardii and Oc. cantans, each, at locality 4, and one individual of Cs. annulata at locality 10.

Significantly fewer mosquitoes were caught with BGS traps, almost five times fewer than with CDC traps. BGS traps also captured a lower number of species (Tab. 1 ). In these traps, the $C x$. pipiens complex was eudominant with a proportion of $86.66 \%$ sampled at localities 1 and 3, further individuals were Ae. geniculatus sampled at location 1. Using human landing catch in Gospić (Fig. 1, locality 1 - purple dot), seven species were recorded: An. plumbeus, Ae. japonicus, Ae. vexans, Ae. geniculatus, Ae. sticticus, Ae. cantans and Cq. richiardii.

Most mosquito samples were collected as larvae in urban (backyards) and rural areas. The largest number of mosquitoes was caught in late July. Overall, the largest proportion belongs to the $C x$. pipiens complex, which was eudominant here with a proportion of $78.36 \%$, and breeding sites of this species were also the most numerous. Dominant species were the invasive Ae. japonicus (9.74\%) and Cs. longiareolata (5.73\%). All other species together accounted for $5.15 \%$ of the larvae collected.

The overview of the recorded species by localities is as follows: species of the $A n$. maculipennis complex at localities 6, 12, 24, 25, 36, 47; An. claviger at localities 6, 23 ,25; An. plumbeus at localities 18, 34, 48, 52; Ae. japonicus at localities 1, 4, 6, 7, 9, 14, 22, 35, 37, 38, 40-45, 47-52; Ae. albopictus at locality 48, Ae. geniculatus at localities 22, 34. Cx. torrentium at localities $24-26,28,30,34,37,40,41,43,45$ and 52; Cx. hortensis at localities 9, 29, 30, 42, 46 and 52; Cx. territans at localities 9, 23, 25, 29 and 4, Cs. longiareolata at localities 2, 4, 6, 9, 12, 13, 16, 22, 23, 27, 28, 33, 39, 40, 43, 44, 49, 51 and 52; Cs. annulata at locality 13 . The most numerous $C x$. pipiens complex was sampled at all localities except 24-26, 28, 30, 34, 37, 40, 41, 43, 45, and 52 (details below).

Within the An. maculipennis complex, only An. maculipennis s.s. individuals were confirmed, all of them occurring in the altitudinal range from 413 to $746 \mathrm{~m}$ a.s.l. (as adults at localities 3, 5, 8 and as larvae at localities 6, 23, 25). Within the Cx. pipiens complex, both biotypes, pipiens $(\mathrm{n}=22)$ and molestus $(\mathrm{n}=1)$, were identified together with one hybrid individual. $C x$. pipiens biotype pipiens was detected at elevations from 401 to $500 \mathrm{~m}$ a.s.l. with eight larvae (sites 6, 7, 23, 46), from 501 to $600 \mathrm{~m}$ a.s.l. with four larvae (sites 10, 21,36), and from 601 to $700 \mathrm{~m}$ a.s.l. with nine larvae (sites $11,13,16,31,32,38$ ) and at $783 \mathrm{~m}$ a.s.1. with one larva (site 19). The single Cx. pipiens biotype molestus larva was detected at an altitude of $758 \mathrm{~m}$ a.s.l. (site 39) and the hybrid larva at an altitude of $613 \mathrm{~m}$ a.s.l. (site 20).

Both invasive mosquito species present in Croatia, Ae. albopictus and Ae. japonicus, were recorded in this study, Ae. albopictus for the first time in Lika. The only individ- 
ual was found in the village of Vojnovac (Fig. 2), in a used tyre at an altitude of $432 \mathrm{~m}$ a.s.l. By contrast, Ae. japonicus was recorded with numerous specimens at an altitudinal range from 493 to $806 \mathrm{~m}$ a.s.l. Its numbers were highest in the northern part of Lika, along the border with Gorski Kotar (Fig. 2). Ae. japonicus was found at 22 out of 52 sites, representing $42.3 \%$ of all sites surveyed. The breeding site with the highest numbers of collected specimens $(n=77)$ was located in Žuta lokva (site 50) at an altitude of $533 \mathrm{~m}$ a.s.l. Depending on the type of habitat, most of the sampled breeding sites were tyres, followed by barrels, buckets and others. Mostly, individuals of $A e$. japonicus were found together with species of the genus Culex, less frequently with species of the genera Culiseta, Anopheles and Aedes (Tab. 2). In 20 of 23 localities, Ae. japonicus was found together with other species, while it was detected alone at only three localities.

Analysis of elevation shows that the largest numbers of specimens and species $(\mathrm{n}=14)$ were collected in an altitude range from 601 to $700 \mathrm{~m}$ a.s.1., and the largest number of sampling sites was also located in this altitudinal range (most of the plateau). The fewest specimens were collected in an altitude range of 901 to $1140 \mathrm{~m}$ a.s.l., which was where the fewest sampling sites were located (Tab. 3). By contrast, the Shannon evenness index and Hill's index show the highest value in this altitudinal

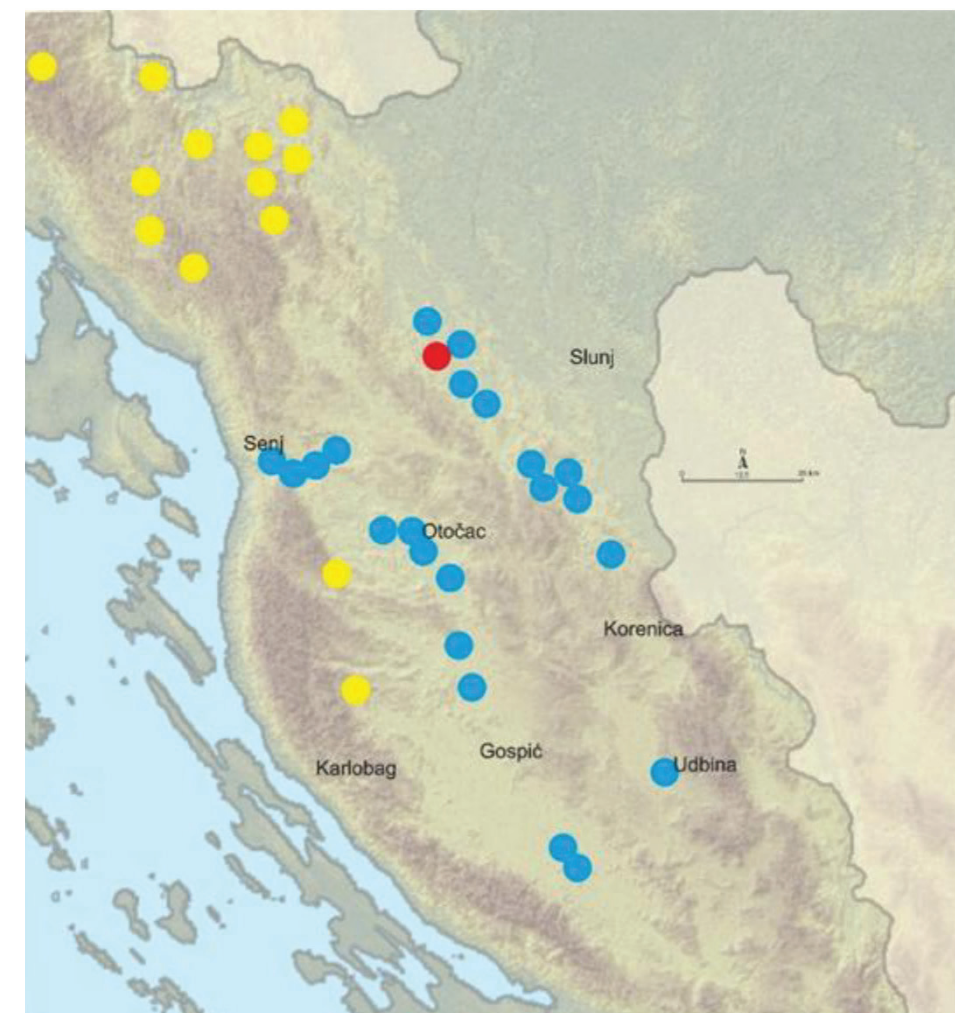

Fig. 2. Distribution of invasive mosquito species of Ae. albopictus (red dot) and Ae. japonicus (blue dot) in Lika. Yellow dots show the distribution of Ae. japonicus according to a previous study (JANSSEN et al., 2020). 
Tab. 2. Number of sites and different habitat types cohabitated by Aedes japonicus and other mosquito species

\begin{tabular}{|l|c|c|c|c|c|}
\hline \multicolumn{1}{|c|}{ habitat type } & barrel & tyre & bathtub & $\begin{array}{c}\text { cemetery } \\
\text { vase }\end{array}$ & bucket \\
\hline \multicolumn{1}{|c|}{ species } & \multicolumn{5}{c|}{ number of sites } \\
\hline An. maculipennis s.s. & 1 & & & & \\
\hline An. claviger & 1 & & & & \\
\hline An. plumbeus & & 1 & & & \\
\hline Ae. albopictus & & 1 & & & \\
\hline Ae. geniculatus & & 1 & & & \\
\hline Cx. pipiens complex & 3 & 7 & 1 & 1 & \\
\hline Cx. torrentium & 2 & 1 & 1 & & \\
\hline Cx. hortensis & 1 & 1 & & & \\
\hline Cx. territans & & 1 & & & \\
\hline Cs. longiareolata & 5 & 4 & 1 & & \\
\hline
\end{tabular}

Tab. 3. Total number of specimens and species collected by altitude along with sampling site

\begin{tabular}{|l|c|c|c|c|c|c|c|}
\hline $\begin{array}{c}\text { species/altitudinal range } \\
\text { (m a.s.1.) }\end{array}$ & $401-500$ & $501-600$ & $601-700$ & $701-800$ & $801-900$ & $\begin{array}{c}901- \\
1140\end{array}$ & total \\
\hline An. maculipennis complex & 16 & 33 & 6 & 25 & 0 & 0 & 80 \\
\hline An. maculipennis s.s. & 9 & 10 & 7 & 5 & 0 & 0 & 31 \\
\hline An. claviger & 20 & 1 & 0 & 0 & 0 & 0 & 21 \\
\hline An. plumbeus & 1 & 0 & 11 & 4 & 0 & 2 & 18 \\
\hline Ae. japonicus & 170 & 111 & 65 & 67 & 78 & 0 & 491 \\
\hline Ae. albopictus & 1 & 0 & 0 & 0 & 0 & 0 & 1 \\
\hline Ae. vexans & 2 & 1 & 6 & 3 & 0 & 0 & 12 \\
\hline Ae. geniculatus & 2 & 4 & 6 & 13 & 2 & 2 & 29 \\
\hline Ae. sticticus & 1 & 9 & 14 & 0 & 0 & 0 & 24 \\
\hline Ae. cantans & 0 & 0 & 2 & 0 & 0 & 0 & 2 \\
\hline Cx. pipiens complex & 474 & 1547 & 1537 & 420 & 16 & 12 & 4006 \\
\hline Cx. torrentium & 5 & 4 & 13 & 8 & 2 & 3 & 35 \\
\hline Cx. hortensis & 3 & 0 & 16 & 0 & 9 & 8 & 36 \\
\hline Cx. territans & 29 & 15 & 2 & 0 & 0 & 0 & 46 \\
\hline Cs. annulata & 0 & 0 & 1 & 1 & 0 & 0 & 2 \\
\hline Cs. longiareolata & 13 & 22 & 190 & 16 & 35 & 14 & 290 \\
\hline Cq. richiardii & 0 & 0 & 2 & 0 & 0 & 0 & 2 \\
\hline number of sampling sites & 16 & 14 & 23 & 9 & 4 & 3 & 69 \\
\hline number of specimens & 746 & 1757 & 1878 & 562 & 142 & 41 & 5126 \\
\hline number of species & 13 & 10 & 15 & 10 & 6 & 6 & 16 \\
\hline
\end{tabular}

range (Fig. 3), where the number of eudominant species was three, while the total number of species was six. The lowest values of the diversity index were obtained in an altitudinal range from 501 to $600 \mathrm{~m}$ a.s.l. Accordingly the number of eudominant species was equal to one, and the total number of species was ten. With altitude increasing, the diversity indices also increased, i.e. the dominance of a single species 


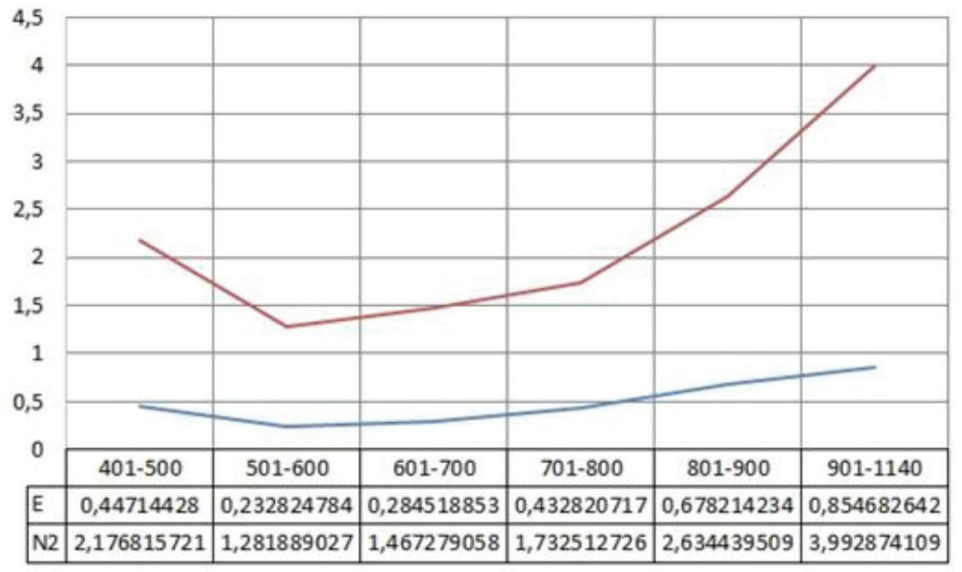

$-\mathrm{E}-\mathrm{N} 2$

Fig. 3. Shannon evenness index (E-blue line) and Hill's index (N2-red line) as a function of altitude

decreased. The only exception was at heights from 401 to $500 \mathrm{~m}$ a.s.l. (Fig. 3). According to Jaccard's similarity index, the highest similarity between localities could be found in the altitudinal ranges from 401 to 500 and 501 to $600 \mathrm{~m}$ a.s.l. (Ja $=0.7692$ ), and in the altitude ranges from 801 to 900 and 901 to $1140 \mathrm{~m}$ a.s.l. (Ja=0.7142). The least similarity was found in the elevation range of 501 to 600 and 901 to $1140 \mathrm{~m}$ a.s.l. $(\mathrm{Ja}=0.3333)$.

\section{DISCUSSION}

Due to the geomorphological and hydrological characteristics, the abundance of mosquitoes in Lika is low. Only a very small number of adult mosquitoes were sampled as compared to larvae (100 out of 5,126 individuals). The larvae were found generally in small to medium sized breeding sites. In addition, these breeding sites were usually located near houses and of were of an artificial nature: barrels, buckets, old tyres dumped in yards, plus gutters and various kinds of debris that retained water and became suitable habitats for mosquito development. In such breeding sites, the house mosquito $C x$. pipiens s. 1 . was primarily sampled, in addition to other species that tolerate extremely cold winters, low water levels and higher elevations.

Sixteen mosquito species were recorded in this study. Another two species ( $A n$. messeae and $A n$. daciae) had been recorded in previous studies (Adamović \& Paulus, 1985; Vignjević, 2014; Bušić et al., 2021), making a total of 18 species recorded in Lika. This number represents $34.6 \%$ of the species known for the Croatian mosquito fauna. This is not a big ratio for such a large area, but considering the particular characteristics and altitude of the Lika region, the number of species is significant.

The fauna of the subfamily Anophelinae had previously been studied in this area, with four species of the genus Anopheles recorded: An. claviger, An. maculipennis s.s., An. messeae and An. daciae (Adamović \& Paulus, 1985; Vignjević, 2014; Bušić et al., 2021). An. claviger had been found in an altitudinal range from 401 to $500 \mathrm{~m}$ a.s.1. (Adamović \& Paulus, 1985), as in our study, with the exception of one individual 
recorded at an altitude of $564 \mathrm{~m}$ a.s.l. It is interesting that larvae of this species were sampled on the margins of the Gacka and Lika rivers, i.e. in slowly flowing water. In our study, the most numerous species within the genus Anopheles was An. maculipennis s.s. A possible reason for not finding $A n$. messeae is that this species prefers larger aquatic habitats, especially floodplains of rivers (BECKER et al., 2010), of which there are very few in the Lika region. By contrast, An. maculipennis s.s. tends to prefer smaller water bodies, which are more frequently represented in the study area. In addition, the elevation of the study area was above $400 \mathrm{~m}$ a.s.l., indicating that the species An. maculipennis s.s. is better adapted to higher altitudes than An. messeae. These data agree with the data of previous studies from other areas, where An. messeae was not found above $200 \mathrm{~m}$ a.s.l., in contrast to individuals of An. maculipennis s.s. and individuals of An. daciae (Kronefeld et al., 2014; Vignjević, 2014; Bušić et al., 2021).

Another species within the subfamily Anophelinae not previously recorded in Lika is An. plumbeus, which was sampled mainly in tyres together with larvae of the $C x$. pipiens complex, Ae. geniculatus and once with Ae. albopictus, as well as in barrels with several other species (Cx. torrentium, $C x$. hortensis, $C s$. longiareolata). It should be emphasized that all habitats were close to the forest, which An. plumbeus prefers (Gutsevich et al., 1974; Becker et al., 2010).

So far, eight species (Cx. pipiens s.s., Cx. torrentium, Cx. hortensis, Ae. japonicus, Ae. geniculatus, Ae. cantans, Cs. annulata, Cs. longiareolata) have been recorded as belonging to the fauna of the Culicinae of Lika (Bušić et al., 2021), which were also recorded in this study, and another four species (Cx. territans, Ae. sticticus, Ae. vexans, Ae. albopictus) have been recorded for the first time in Lika in this study.

In the last few years, the invasive Asian tiger mosquito Ae. albopictus and the Asian rock pool mosquito Ae. japonicus have spread throughout Europe, including Croatia (CAminade et al., 2012; Medlock et al., 2012; KlObuČar et al., 2019; Koban et al., 2019; JANSSEN et al., 2020). Ae. albopictus has been detected in all counties of Croatia (CAPAK et al., 2017), while this is the first finding for the geographical region of Lika. During a study conducted in this area in 2017, not a single individual of Ae. albopictus was recorded (Bušić et al., 2021). On the other hand, two individuals of Ae. japonicus were detected in this area in the locality of Baške Oštarije and Kuterevo (JANSSEN et al., 2020), while the present study recorded a notable increase in the area occupied by this species. It can be assumed that Ae. japonicus has spread from the area of Gorski Kotar to the area of Lika since 2017, as indicated by the largest number of sampled individuals found directly on the border with Gorski Kotar. As in previous studies (Kaufman \& Fonseca, 2014; Cunze et al., 2016; Zielke et al., 2016; Montarsi et al., 2019; Bušić et al., 2021), our results confirm the good adaptation of this species to higher altitudes and colder temperatures as well as the possibility of cohabitation with other species, especially those of the genus Culex.

The study area extends mainly at higher altitudes (around $600 \mathrm{~m}$ a.s.1.), which could be one of the reasons why we recorded the largest number of localities and species, as well as a large number of different habitats, in these altitudinal range from 601 to $700 \mathrm{~m}$ a.s.l. Although altitude is a natural barrier, mosquitoes were also found in a range from 901 to $1140 \mathrm{~m}$ a.s.l., as in other recent studies (MUJA-BAJRAKTARI et al., 2019; Bušić et al., 2021). The Shannon evenness index and Hill's index showed a high value in the altitudinal range from 901 to $1140 \mathrm{~m}$ a.s.l., indicating a more uniform abundance of species. 
Since the fauna of Lika has only been sporadically examined so far, this is the first systematic study of the fauna of mosquitoes of Lika. Of course, it should be noted that this study probably did not cover all species inhabiting this area, which gives space for further research. Based on the observed spread of the invasive species $A e$. japonicus in this area since 2017 and the recording of the invasive species Ae. albopictus, it is reasonable to assume that the spread will continue and to suggest that it should be monitored.

\section{ACKNOWLEDGMENTS}

This study was supported by internal funding of the Department of Biology, Josip Juraj Strossmayer University of Osijek. Part of this study was conducted in the framework of the project "DNA barcoding of Croatian faunal biodiversity" (IP-06-20169988).

Received March 15, 2021

\section{REFERENCES}

Adamović, Ž. \& Paulus, R., 1985: A new survey of Anophelinae mosquitoes (Diptera, Culicidae) in Lika, Yugoslavia. Glasnik Prirodnjačkog Muzeja 40, 169-174.

Bahnck, C.M. \& FonseCA., D.M. 2006: Rapid assay to identify the two genetic forms of Culex (Culex) pipiens L. (Diptera: Culicidae) and hybrid populations. American Journal of Tropical Medicine and Hygiene 75(2), 251-255.

Becker, N., Petric, D., Zgomba, M., Boase, C., Madon, M.B., Dahl, C. \& Kaiser, A., 2010: Mosquitoes and their control. Heidelberg Springer, Berlin. $498 \mathrm{pp}$.

Bušić, N., KuČinić, M., Merdić, E. \& Bruvo-Mąarić, B., 2021: Diversity of mosquito fauna (Diptera, Culicidae) in higher-altitude regions of Croatia. Journal of Vector Ecology 46(1), 65-75.

Caminade, C., Medlock, J.M., Ducheyne, E., Mcintyre, K.M., Leach, S., Baylis, M. \& Morse, A.P., 2012: Suitability of European climate for the Asian tiger mosquito Aedes albopictus: recent trends and future scenarios. Journal of The Royal Society Interface 9(75), 2708-17.

Capak, K., Jeličić, P., Janev Holcer, N., Trumbetić, I., Klobučar, A., Landeka, N., Žitko, T., Sikora, M., Bokan, I., Merdić, E., Krešić, K., Cvitrović, A., Lipovac, I., Medić, A., Slavić-Vrzić, V., Klemenčić, M., Slavica, S., Stanković, A., Mitrović Hamzić, S., Fič́o, I., Vrsaljko, Z., Hranilović, B., Grgić I., Stanić, I. \& Putarek, I., 2017: Nationalni monitoring invazivnih vrsta komaraca u Hrvatskoj u 2016. Zbornik radova 29. Znanstveno-stručno-edukativnog seminara DDD i ZUPP, pp 34-51.

Cunze, S., Кoch, L.K., Kochmann, J. \& Klimpel, S., 2016: Aedes albopictus and Aedes japonicus - two invasive mosquito species with different temperature niches in Europe. Parasite \& Vectors 9, 573.

Di Luca, M., Boccolini, D., Marinuccil, M. \& Romi, R., 2014: Intrapopulation polymorphism in Anopheles messeae (Anopheles maculipennis complex) inferred by molecular analysis. Journal of Medical Entomology 41(4), 582-586.

Drozd, P., 2010: ComEcoPaC - Community Ecology Parameter Calculator. Version 1. http:/ /prf.osu. $\mathrm{cz} / \mathrm{kbe} /$ dokumenty/sw/ComEcoPaC/ComEcoPaC.xls. Accessed on 20 February 2021.

Gimnig, J.E., Hightower, A.W. \& Hawley, W.A., 2005: Application of geographic information systems to the study of the ecology of mosquitoes and mosquito-borne diseases. In: TAKKen, W., Martens, P. \& Bogers, R.J. (eds) Environmental change and malaria risk: global and local implications. Springer, Dordrecht, pp 15-26.

Gutsevich, A.V., MonchadskiI, A.S. \& Shtakelberg, A.A., 1974: Fauna of the USSR. Diptera III (4). Jerusalem, $374 \mathrm{pp}$.

Hebert, P.D., Cywinska, A., Ball, S.L. \& Dewaard, J.R., 2003: Biological identifications through DNA barcodes. Proceedings of the Royal Society B: Biological Sciences 270(1512), 313-321. 
Hongoh, V., Berrang-Ford, L., Scott, M. E. \& LindsaY, L. R., 2012: Expanding geographical distribution of the mosquito, Culex pipiens, in Canada under climate change. Applied Geography 33, $53-62$.

Janssen, N., Graovac, N., Vignjević, G., Sudarić Bogojević, M., Turić, N., Klobučar, A., Kavran, M., Petrić, D., Ignjatović Ćupina, A., Fischer, S., Werner, D., Kampen, H. \& Merdić, E., 2020: Rapid spread and population genetics of Aedes japonicus japonicus (Diptera: Culicidae) in southeastern Europe (Croatia, Bosnia and Herzegovina, Serbia). PLoS One 15(10), e0241235.

Kaufman, M.G. \& Fonseca, D.M., 2014: Invasion biology of Aedes japonicus japonicus (Diptera: Culicidae). Annual Review of Entomology 59, 31-49.

Khrabrova, N.V., Andreeva, Y.V., Vaulin, O.V., Alekseeva, S.S. \& Sibataev, A.K., 2013: Variability of the mitochondrial cytochrome oxidase subunit I gene sequence in species of the genera Aedes and Ochlerotatus (Diptera: Culicidae). Russian Journal of Genetics: Applied Research 3, 279-286.

Klobučar, A., Merdić, E., Benić, N., Baklaić, Z. \& KrČmar, S., 2006: First record of Aedes albopictus in Croatia. Journal of the American Mosquito Control Association 22(1), 147-148.

Klobučar, A., Lipovac, I., Benić, N. \& KrajCAR, D., 2014: New record of invasive mosquito species in the northwestern Croatia during 2013. Zbronik radova 26. znanstveno - stručno - edukativnog seminara DDD i ZUPP 2014., pp 49-59.

Klobučar, A., Lipovac, I., Žagar, N., Mitrović-Hamzić, S., Tešić, V., Vilibić-Čavlek, T. \& Merdić, E., 2019: First record and spreading of the invasive mosquito Aedes japonicus japonicus (Theobald, 1901) in Croatia. Medical and Veterinary Entomology 33, 171-176.

Koban, M.B., Kampen, H., Scheuch, D.E., Frueh, L., Kuhlisch, C., Janssen, N., Steidle, J.L.M., Schaub, G.A. \& Werner, D., 2019: The Asian bush mosquito Aedes japonicus japonicus (Diptera: Culicidae) in Europe, 17 years after its first detection, with a focus on monitoring methods. Parasite \& Vectors 12, 109.

Kronefeld, M., Werner, D. \& Kampen, H., 2014: PCR identification and distribution of Anopheles daciae (Diptera, Culicidae) in Germany. Parasitology Research 113(6), 2079-2086.

Montarsi, F., Martini, S., Michelutti, A., Da Rold, G., Mazzucato, M., Qualizza, D., Di Gennaro, D., Di Fant, M., Dal Pont, M., Palei, M. \& Capelli, G. 2019: The invasive mosquito Aedes japonicus japonicus is spreading in northeastern Italy. Parasites \& Vectors 12, 120.

Medlock, J.M., Hansford, K.M., Schaffner, F., Versteirt, V., Hendrickx, G., Zeller, H. \& Van BorTEL., W., 2012: A review of the invasive mosquitoes in Europe: ecology, public health risks, and control options. Vector Borne Zoonotic Diseases 12(16), 435-447.

Merdić, E., Kujavec, M., Kovačević, M., Žulj, M., Graovac, N., Vignjević, G. \& Turić, N., 2018: Culex torrentium (Martini), a new species in Croatian mosquito fauna. Natura Croatica 27(2), 323-329.

Merdić, E., Vrućina, I., Klobučar, A., Sudarić Bogojević, M., Vignjević, G., Turić, N., Žitko, T. \& Bušıć, N., 2020a: Komarci Hrvatske. Sveučilište Josipa Jurja Strossmayera u Osijeku, Odjel za biologiju, Osijek, pp 89-102.

Merdić, E., Klobučar, A., Sudarić Bogojević, M., Turić, N., Vignjević, G., Vrućina, I. \& Žitko, T., 2020b: Updated checklist of the mosquitoes (Diptera: Culicidae) of Croatia. Journal of Vector Ecology 45(1), 135-139.

Muja-Bajraktari, N., Zhushi-Etemi, F., Dikolli-Velo, E., Kadriaj, P. \& Gunay, F., 2019: The composition, diversity, and distribution of mosquito fauna (Diptera, Culicidae) in Kosovo. Journal of Vector Ecology 44(1), 94-104.

Palaniyandi, M., 2014: Web mapping GIS: GPS under the GIS umbrella for Aedes species dengue and chikungunya vector mosquito surveillance and control. International Journal of Mosquito Research 1(3), 18-25.

Smith, J.L. \& FonseCa, D.M., 2004: Rapid assays for identification of members of the Culex (Culex) pipiens complex, their hybrids, and other sibling species (Diptera: Culicidae). American Journal of Tropical Medicine and Hygiene 70(4), 339-345.

Vignjević, G., 2014: Molecular identification and distribution of mosquito species Anopheles maculipennis complex in Croatia. Ph.D. thesis, Josip Juraj Strossmayer University of Osijek, Croatia, $75 \mathrm{pp}$.

Zielke, D.E., Walther, D. \& Kampen, H., 2016: Newly discovered population of Aedes japonicus japonicus (Diptera: Culicidae) in Upper Bavaria, Germany, and Salzburg, Austria, is closely related to the Austrian/Slovenian bush mosquito population. Parasite \& Vectors 9, 163. 